\title{
Chemical characterization of Amazonian non-polar vegetal extracts (buriti, tucumã, Brazil nut, cupuaçu, and cocoa) by infrared spectroscopy (FTIR) and gas chromatography (GC-FID)
}

Caracterização química de extratos vegetais não-polares da Amazônia (buriti, tucumã, castanha do Pará, cupuaçu e cacau) por espectroscopia de infravermelho e cromatografia gasosa (GC-FID)l

Recebido em: $14 / 07 / 2019$ Aceito em: $16 / 09 / 2019$
Barbara LEONARDI ${ }^{1,2}$; Luciana Juncioni de ARAUZ ${ }^{3}$; Julia BARUQUE-RAMOS ${ }^{1}$

${ }^{I}$ School of Arts, Sciences and Humanities, University of São Paulo. Av. Arlindo Bettio, 1000, CEP 03828000. São Paulo, SP, Brazil.

${ }^{2}$ Golden Technology. R. Ambrosio Molina, 1100, CEP 12247902. São José dos Campos, SP, Brazil. ${ }^{3}$ Laboratory of Inorganic Contaminants Adolfo Lutz Institute. Av. Dr. Arnaldo, 355, CEP 01246-902. São Paulo, SP, Brazil.

E-mail: leonardi.ba@gmail.com

\section{ABSTRACT}

Amazonian biodiversity products have economic importance mainly in food, pharmaceutical, and cosmetic industries, despite their possibilities of applications has not been extensively developed. This study aimed to perform the chemical characterization of Amazonian non-polar vegetal extracts (buriti oil, tucumã butter, Brazil nut oil, cupuaçu butter, and cocoa butter) employing Fourier transform infrared spectroscopy (FTIR) and gas chromatography with flame-ionization detection (GC-FID). FTIR analysis presented similar spectra whose assignments were based on the correlations with fatty acids. For all extracts, the obtained percentage of fatty acids in the present study presented similarities in comparison to data reported in previous literature. Respect the variations, considered in terms of composition and percentages, could be attributed to the differences of origin of oils, sample conditioning/storage and/or experimental conditions. Finally, the presented findings could be useful to future researches for the chemical characterization and application of Amazon flora extracts, as well as, production of products in food, pharmaceutical, cosmetic, textile and other industrial sectors.

Keywords: Amazonia; vegetal native products; oil; butter, chemical composition.

\section{RESUMO}

Os produtos da biodiversidade amazônica têm importância econômica principalmente nas indústrias alimentícia, farmacêutica e cosmética, apesar das possibilidades de aplicações não terem sido amplamente desenvolvidas. Este trabalho teve como objetivo realizar a caracterização química de extratos vegetais não-polares da Amazônia (óleo de buriti, manteiga de tucumã, óleo de castanha do Pará, manteiga de cupuaçu 
e manteiga de cacau) por espectroscopia de infravermelho com transformada de Fourier (FTIR) e cromatografia gasosa com detecção por ionização de chama (GC-FID). A análise por FTIR apresentou espectros semelhantes, cujas atribuições foram baseadas em correlações com ácidos graxos. Para todos os extratos, as porcentagens obtidas de ácidos graxos no presente estudo mostraram semelhanças em relação aos dados apresentados na literatura. Com relação às variações, consideradas em termos de composição e percentuais, podem ser atribuídas a diferenças de origem dos óleos, condicionamento/armazenamento das amostras e/ou condições experimentais. Finalmente, os dados apresentados podem ser utilizados em futuras pesquisas na caracterização química e aplicação de extratos da flora amazônica, bem como para a produção de produtos nos setores alimentício, farmacêutico, cosmético, têxtil e outros setores industriais.

Palavras-chave: Amazônia; produtos vegetais nativos; óleo; manteiga; composição química.

\section{INTRODUCTION}

The Amazonian region presents enormous biodiversity and is considered the most significant natural reservoir of vegetal diversity in the planet and houses a large variety of fruit crops, some of which have potentially promising health and nutritional properties $(1,2)$. Additionally, Brazil owns $20 \%$ of all the biodiversity in the world, but unfortunately, only $10 \%$ of all plant species have been included in chemical or biological studies (3).

In the Amazonian region, there are countless species whose products can contribute to meet the demand for seeds, fruit, nuts, and their oleaginous oils. Vegetable oils from the Amazon are used by some industries but remain small exploited commercially (4). However, the demand for vegetable oils with unique composition is increasing, and oils obtained from native palm fruits, which are complex mixtures of organic compounds (5), can be considered as new sources that will surely have their increased commercial value (6).

The extracts already studied from native Amazonian plants generally are composed of a complex mixture of triglycerides and remainder constituents, which are usually free fatty acids, monoglycerides, diglycerides, and others with small concentration: tocopherols, carotenoids, and sterols (7). Some of them, known commercially as buriti oil, tucumã butter, Brazil nut oil, cupuaçu butter, and cocoa butter, are commonly used in pharmaceutical and cosmetic areas, however can also present potential applicability in the textile area such as for the manufacture of fabric softeners and other products. Notably, the application of plant extracts for use in textile processing can be a sustainable and environmentally friendly alternative to current raw materials used by this market (8).

Buriti (Mauritia flexuosa) is a palm widely distributed in the Brazilian Amazon rain forest. It has high economic potential, due mainly to its fruits, from which a valuable oil is extracted. The buriti fruit can generate two types of oil with potential use in cosmetic, chemical, and food industries. From the fruit pulp, the obtained oils are rich in oleic acids; while seeds are rich in lauric acid. The pulp oil has a high content of carotene in nature (pro-Vitamin A), and this characteristic makes this oil useful for the manufacture of sunscreen $(4,9)$.

Tucumã (Astrocaryum vulgare) is a palm with an orange-yellow fruit (about the size of a chicken egg), which is an excellent source of carotenoids. It is distributed in the central region of the Brazilian Amazon basin, and it also is present in Bolivia, Guyana, Suriname, Trinidad, and Venezuela. The tucumã butter is obtained from the seeds (kernels) and fruit pulp, using a natural process of cold pressure extraction without solvents or chemical substances $(10,11)$. The centesimal composition analysis of the tucumã, employing methods described by the Association of Official Analytical Chemists (AOAC), showed that its mesocarp presents per $100 \mathrm{~g}$ of pulp: $412.73 \pm 2.12 \mathrm{kcal}, 44.9 \pm$ $0.30 \mathrm{~g}$ wet content, $10.9 \pm 0.1 \mathrm{~g}$ fibers, $3.5 \pm$ $0.07 \mathrm{~g}$ proteins, $8.5 \pm 0.6 \mathrm{~g}$ carbohydrates and $40.5 \pm 0.5 \mathrm{~g}$ fats. The oil extracted from tucumã consists of $74.4 \%$ unsaturated, and $25.6 \%$ saturated fatty acids and is rich in omega-3, - 
6, and - 9 fatty acids. Additionally, the edible tucumã fruit can also to be employed for the production of biodiesel $(12,13)$.

Brazil nut (Bertholletia excelsa) is from a tree and presents important antioxidant properties due to its selenium content. Moreover, even though an average of $60 \%$ of their total weight is oil, $73 \%$ of the fatty acids are monounsaturated and polyunsaturated heart-protective, and it is an excellent dietary source of micronutrients such as tocopherols, phytosterols, and squalene (14). The contents of water, carbohydrate, protein and total lipid of Brazil nut are 3.5\%,12.3\%,14.3\%, and $66.4 \%$, respectively (15).

Cupuaçu tree (Theobroma grandiflorum) is found in the Brazilian Amazonian rain forest. Its pulp has high consumer acceptance and is used for the preparation of juices, ice creams, candies, creams, jams, desserts, and liquors $(16,17)$. The seeds, from which are extracted cupuaçu seed oil, have high fat content $(62 \%)$ with characteristics that resemble those from cocoa butter and with potential applications in the cosmetic, pharmaceutical and food industries (18).

Cocoa butter is a light-yellow fat obtained from butter bean of the cocoa plant (Theobroma cacao), highly demanded by food, pharmaceutical, and cosmetic industries. Moreover, it is unique among vegetable fats due to composition and crystallization behavior. Cocoa butter is the only commercially available as natural fat which is rich in saturated and monounsaturated fatty acids $(19,20)$.

In this way, the aim of the present study was to perform the chemical characterization of Amazonian non-polar vegetal extracts (buriti oil, tucumã butter, Brazil nut oil, cupuaçu butter and cocoa butter) employing Fourier transform infrared spectroscopy (FTIR) and gas chromatography with flame-ionization detection (GC-FID), to compare the obtained results each other and with former literature.

\section{MATERIAL AND METHODS}

Amazonian vegetal extracts and reagents. The Amazonian non-polar vegetal extracts were obtained from Inovam Brasil exports LTD
Company (Rondonia State, Brazil), namely: (i) buriti oil, (ii) tucumã butter, (iii) Brazil nut oil, (iv) cupuaçu butter and (vi) cocoa butter.

All employed reagents were of analytical grade unless otherwise specified. Solutions were prepared with high purity deionized water (resistivity 18.2 $\mathrm{M} \Omega . \mathrm{cm}$ ) from a Millipore water purification system (Bedford, NY, USA).

Fourier transform infrared spectroscopy (FTIR). The extracts were analyzed employing Fourier Transform Infrared Spectroscopy (FTIR) analyzer from Thermo Fisher Scientific model Avatar 370 FTIR (Waltham, MA, USA) equipped with Omnic $\AA$ version 4.1 software (21). The infrared (IR) measurements were performed within the region 4000 to $700 \mathrm{~cm}^{-1}$ using a $\mathrm{NaCl}$ cell. Each measurement produced by the instrument was the average of 32 scans at a wavelength resolution of $2 \mathrm{~cm}^{-1}$. Blank preparation (empty cell) before analysis of samples was carried out in order to ensure the absence of spectral interferences. Measurements were performed directly on the cell, without the need of sample preparation. All spectra were obtained in duplicate.

Gas chromatography with flame-ionization detection (GC-FID). In order to perform the derivatization, a sample of vegetal extract (50 to $100 \mathrm{mg}$ ) was mixed with $4 \mathrm{~mL}$ of methanol sodium hydroxide $0.5 \mathrm{M}$ in a tube covered and heated in a boiling water bath for $5 \mathrm{~min}$. After cooling, $5 \mathrm{~mL}$ of a solution prepared formerly (ammonium chloride $2.0 \mathrm{~g}$ in concentrated sulfuric acid $3.0 \mathrm{~mL}$ diluted in methanol $60 \mathrm{ml}$ and refluxed during $15 \mathrm{~min}$ ) was added. It was heated for $5 \mathrm{~min}$ in boiling water bath. After cooling, $5 \mathrm{~mL}$ of hexane was added to the solution and shaken vigorously for $1 \mathrm{~min}$. The organic phase was transferred to a vial to be analyzed.

The analysis of the prepared extracts was carried out in the equipment Agilent 6890 N GCFID system, equipped with a flame ionization detector (FID) on an Agilent capillary column, DB-23 $(60 \mathrm{~m} \times 0.25 \mathrm{~mm}$; film thickness 0.25 $\mu \mathrm{m})$ (Agilent Technologies, USA). The column temperatures of injector and detector were set at $250{ }^{\circ} \mathrm{C}$ and $280{ }^{\circ} \mathrm{C}$, respectively. Hydrogen was 
used as carrier gas, in a flow rate of $1.0 \mathrm{~mL} / \mathrm{min}$. The injected volume was $1.0 \mu \mathrm{L}$ of the prepared sample in split mode $(50: 1)$ under the following experimental conditions: synthetic gas flow rate of $350 \mathrm{~mL} / \mathrm{min}$ and nitrogen flow rate at column of 15 $\mathrm{mL} / \mathrm{min}$.

The oven temperature was initially held at $195{ }^{\circ} \mathrm{C}$ for $20 \mathrm{~min}$, then programmed to heat at a rate of $5{ }^{\circ} \mathrm{C} / \mathrm{min}$ until reaching $215^{\circ} \mathrm{C}$, maintaining this temperature for $6 \mathrm{~min}$. The concentration of compounds was calculated by comparing the peak area of the analyte in the sample with the peak area of the standard of a known concentration using Agilent GC ChemStation ${ }^{\circledR}$ software installed in the computer (22).

\section{RESULTS AND DISCUSSION}

Analysis of results of Fourier transform infrared spectroscopy (FTIR). Infrared absorption spectra of tucumã butter, Brazil nut oil, cupuaçu butter, and cocoa butter are shown in Figure 1. The spectra present similar profiles, except for buriti oil spectrum, in which the peak at $1711 \mathrm{~cm}^{-1}$ was not observed in any others.

Relevant infrared bands and assignments of all studied vegetal extracts (buriti oil, tucumã butter, Brazil nut oil, cupuaçu butter, and cocoa butter) are displayed in Table 1, and the analysis of their chemical bonding was based on FTIR studies developed by Stuart (2005) (23).

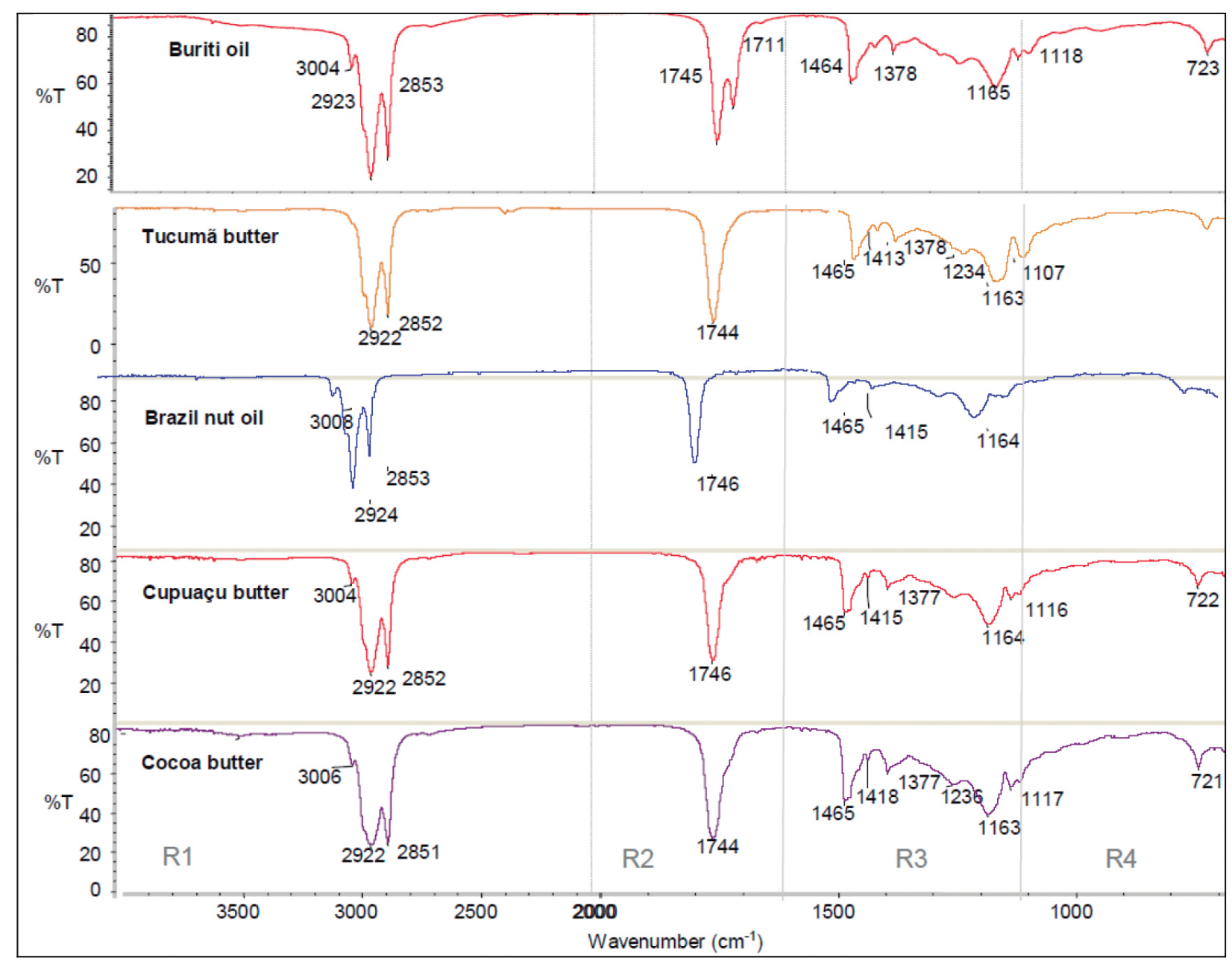

Figure 1. Infrared absorption spectra of (from top to bottom): (a) buriti oil, (b) tucumã butter, (c) Brazil nut oil, (d) cupuaçu butter and (e) cocoa butter. 
In order to analyze the infrared spectra, they were divided into four regions as follows: (i) R1 (4000-2000 $\left.\mathrm{cm}^{-1}\right)$, (ii) R2 (2000-1600 $\left.\mathrm{cm}^{-1}\right)$, (iii) R3 (1600-900 $\left.\mathrm{cm}^{-1}\right)$, and (iv) R4 $\left(<900 \mathrm{~cm}^{-1}\right)$. In the $\mathrm{R} 1$ region, three known spectral bands are clearly visible. The peaks at $3008-3004 \mathrm{~cm}^{-1}$ can be attributed to the presence of $\mathrm{CH}$ stretching related to $=\mathrm{C}-\mathrm{H}$ bonding. This peak was not observed in tucumã butter spectrum (Figure 1 and Table 1). Other bands at 2924-2922 $\mathrm{cm}^{-1}$ can be assigned to the C-H asymmetric stretching of a methylene group. This peak is presents in these four analyzed spectra. Lastly, in R1 a peak at 2853-2851 $\mathrm{cm}^{-1}$ can be observed and corresponds to symmetric stretching of methylene $(\mathrm{C}-\mathrm{H})$ group. It was also observed in four analyzed spectra.

The intense band at $1746-1744 \mathrm{~cm}^{-1}$ was observed in R2 region (2000-1600 $\left.\mathrm{cm}^{-1}\right)$ and it is attributed to aliphatic ester $\mathrm{C}=\mathrm{O}$ stretching. According to Stuart (2005), two polar bonds which are present in the majority of esters (containing CO-O-C - bond) such as $\mathrm{C}=\mathrm{O}$ and $\mathrm{C}-\mathrm{O}$, produce strong IR bands (23). The region 2000-1700 $\mathrm{cm}^{-1}$ could be assigned as overtone and combination of aromatic compounds bands. Aliphatic esters have bands $\mathrm{C}=\mathrm{O}$ and $\mathrm{C}-\mathrm{O}$ at $1750-1730 \mathrm{~cm}^{-1}$ and 1300 $1100 \mathrm{~cm}^{-1}$ respectively, whereas aromatic esters have bands $\mathrm{C}=\mathrm{O}$ and $\mathrm{C}-\mathrm{O}$ at $1730-1705$ and 1300 $1250 \mathrm{~cm}^{-1}$, respectively. On other hand, aliphatic and aromatic ketones show carbonyl bands at 1730-1700 and 1700-1680 $\mathrm{cm}^{-1}$, respectively, while aliphatic and aromatic aldehydes produce carbonyl bands in the $1740-1720 \mathrm{~cm}^{-1}$ and 1720 $1680 \mathrm{~cm}^{-1}$ ranges, respectively.

The third region, called R3, presents a peak of medium intensity at $1465 \mathrm{~cm}^{-1}$, which corresponds $\mathrm{CH}_{2}$ scissoring band. At $1418-1413 \mathrm{~cm}^{-1}$, the observed peak is assigned to a $\mathrm{C}-\mathrm{O}-\mathrm{H}$ in-plane deformation. The band at $1378-1377 \mathrm{~cm}^{-1}$ indicates a $\mathrm{CH}_{3}$ symmetrical deformation. Another peak at $1165-1163 \mathrm{~cm}^{-1}$ is related to aliphatic ester' $\mathrm{C}-\mathrm{O}$ bond. The other bands are related to fingerprint region that can be overlapping bands, considering the region near $1000 \mathrm{~cm}^{-1}$ is known as Stuart fingerprint (23). However, many vibrations do not always produce the same behavior and can vary by hundreds of wave numbers, even for similar molecules. This applies to the majority of bonds that have vibrations absorbed in the region of $1500-650 \mathrm{~cm}^{-1}$ which has small steric or electronic effects on the molecules and may lead to chemical modifications. It is known that a spectrum of a molecule may present hundreds of absorption bands, but there is no need to correlate most of them.

The next region to be analyzed in $\mathrm{R} 4(<900$ $\mathrm{cm}^{-1}$ ) reveal a band around to $720 \mathrm{~cm}^{-1}$ with a $\mathrm{CH}_{2}$ rocking deformation, indicating the presence of four or more $\mathrm{CH}_{2}$ groups forming a chain.

Table 1. Bond vibrations at wavenumber of vegetal extracts: buriti oil, tucumã butter, Brazil nut oil, cupuaçu butter, and cocoa butter. The results were analyzed based on the studies developed by Stuart (2005) (23).

\begin{tabular}{|c|c|c|c|c|c|}
\hline \multicolumn{7}{|c|}{ Wavenumber $\left(\mathbf{c m}^{-1}\right)$} & \multirow{2}{*}{ Assignment } \\
\hline \multirow{2}{*}{ Buriti oil } & $\begin{array}{c}\text { Tucumã } \\
\text { butter }\end{array}$ & $\begin{array}{c}\text { Brazil } \\
\text { nut oil }\end{array}$ & $\begin{array}{c}\text { Cupuaçu } \\
\text { butter }\end{array}$ & $\begin{array}{c}\text { Cocoa } \\
\text { butter }\end{array}$ & =C-H stretching \\
\hline 3004 & - & 3008 & 3004 & 3006 & C-H methylene asymmetry stretching \\
\hline 2923 & 2922 & 2924 & 2922 & 2922 & C-H methylene symmetry stretching \\
\hline 2853 & 2852 & 2853 & 2852 & 2851 & C=0 aliphatic stretching \\
\hline 1745 & 1744 & 1746 & 1746 & 1744 & C=0 stretching \\
\hline 1711 & - & - & - & - & Methylene scissoring \\
\hline 1464 & 1465 & 1465 & 1465 & 1465 & C-0-H bending (in-plane) \\
\hline 1378 & 1416 & - & 1415 & 1418 & C-H symmetrical flexion of methyl \\
\hline- & 1378 & 1378 & 1377 & 1377 & C-0 stretching \\
\hline 723 & 1234 & - & - & 1326 & C-0 stretching aliphatic \\
\hline
\end{tabular}


In the spectrum of buriti oil (Figure 1 and Table 2) was observed a peak in the region at 1711 $\mathrm{cm}^{-1}$ that could be assigned to $\mathrm{C}=\mathrm{O}$ stretching according to studies by Stuart (23). This peak was not observed in any of the other spectra at present study.

Albuquerque et al. (2003) reported the infrared absorption spectra of buriti, copaiba, babaçu and andiroba oils (1). In that study, Fourier-transform infrared spectra were obtained from a Spectrum One FTIR Spectrometer with a spectral resolution of $1 \mathrm{~cm}^{-1}$. For buriti oil, the spectrum was obtained through the horizontal attenuated total reflectance (HATR) technique using a $\mathrm{ZnSe}$ crystal. Eight spectra in the region 650-4000 $\mathrm{cm}^{-1}$ were run, and the averaged spectrum was plotted as a percent transmittance curve versus wavenumbers.

Despite differences in the methodologies, the spectrum obtained by those authors for buriti oil was similar to the obtained in the present study (Figure 1). In order to perform a more thorough analysis, the comparison between the interpretation of results obtained in the present study and those reported by Albuquerque et al. (2003) (1) are presented in Table 2.
Comparing all results presented in Table 2, few differences were found among them. Including, some of them could be attributed to the variations of origin of the oils, sample conditioning/storage and/or experimental conditions. For example, according those own authors of that study (1), for the buriti oil the "spectra of fatty acids it is undoubtedly assigned to the stretching vibration of $\mathrm{OH}$ group". In the proposed model for the formation of buriti oil molecule, no $\mathrm{OH}$ groups are present. However, due to humidity some $\mathrm{H}_{2} \mathrm{O}$ molecules can be present, therefore resulting in the observation of this band. It is worthy of mention that in the present study this band was not observed, indicating absence of humidity and proper conservation of the sample (1).

At last, they concluded that "the assignments for the infrared bands were based on the correlations with fatty acids, esters, and triglycerides of fatty acids and similar results found for other vegetable oils. It is observed that the spectrum of buriti oil is very similar to that of triolein, a triglyceride of oleic acid. This result not only indicates which is the formation process of the buriti oil molecule but opens the possibility of using it to avoid lowdensity lipoprotein (LDL) cholesterol" (1).

Table 2. Comparison of bond vibrations at wavenumber of buriti oil between the results obtained in the present study and reported in the literature (1).

\begin{tabular}{|c|c|c|}
\hline \multicolumn{2}{|c|}{ Wavenumber $\left(\mathrm{cm}^{-1}\right)$} & \multirow{2}{*}{ Assignment } \\
\hline Present study & (1) & \\
\hline- & 3475 & $\mathrm{OH}$ stretching \\
\hline 3004 & 3006 & $=\mathrm{C}-\mathrm{H}$ stretching \\
\hline- & 2954 & $\mathrm{CH}_{3}$ asymmetry stretching \\
\hline 2923 & 2922 & $\mathrm{CH}_{2}$ asymmetry stretching \\
\hline 2853 & 2854 & $\mathrm{CH}_{2}$ symmetry stretching \\
\hline 1745 & 1744 & $\mathrm{C}=0$ stretching \\
\hline 1711 & - & - \\
\hline- & 1655 & $\mathrm{C}=\mathrm{C}$ stretching \\
\hline 1464 & 1464 & $\mathrm{CH}_{2}$ scissors \\
\hline 1378 & - & - \\
\hline- & $1290-1040$ & $C=C-C-0$ \\
\hline 1165 & - & C-0 aliphatic stretching \\
\hline 723 & 722 & $\mathrm{CH}_{2}$ methylene rocking \\
\hline
\end{tabular}

* The results were analyzed based on the studies developed by Stuart (2005) (23). 
GAS CHROMATOGRAPHY WITH FLAME-IONIZATION DETECTION (GCFID) ANALYSIS

The results from gas chromatography with flame-ionization detection (GC-FID) analysis of the vegetable extracts are shown in Table 3. In all cases, there was no detection of fatty acids with more than 22 carbons. The retention time (based on analytical standards) of buriti oil, Brazil nut oil, cupuaçu butter and cocoa butter have basically the same characteristics even though they have different percentages of palmitic (C16:0), palmitoleic (C16:1), margaric (C17:0), stearic (C18:0), oleic (C18:1), linoleic (C18:2), linolenic (C18:3) and behenic (C22:0) acids in their composition. The tucumã butter presented in its composition significant amounts of caprylic (C8:0), capric (C10:0), lauric (C12:0), myristic (C14:0) and palmitic (C16:0) acids.

Analysis of buriti oil. Several reports (1,2426) indicated that buriti oil is composed of fatty acids as follow: oleic - C18:1 (73.3-78.73\%), palmitic - C16:0 (17.34-19.2\%), linoleic - C18:2 (2.4-3.93\%), stearic - C18:0 (2.0\%) and myristic C14:0 (0.1\%). According them some analysis still showed traces of palmitoleic acid (C16:1).

Morais and Gutjahr (2009) reported the following composition of fatty acids: valeric C5:0 (0.95\%), myristic - C14:0 (0.1\%), palmitic - C16:0 (17.44\%), stearic - C18:0 (2.18\%), oleic 18:1 (70.55\%), linoleic - C18:2 (7.03\%), linolenic C18:3 (1.08\%), arachidic C20:0 (0.27\%) and gadoleic $(0.3 \%)(11)$.

In Table 4 is shown the comparison of the reported results and those obtained in the present study. The majority contents are oleic, palmitic, and linoleic acids (totalizing above 90\%). However, the values of the smaller fractions of the fatty acids in buriti oil are diversified. These variations could be attributed to the variations of origin of buriti oil, sample conditioning/storage and/or variations of experimental conditions in each study.

Table 3. Chemical composition obtained by GC-FID analysis from buriti oil, tucumã butter, Brazil nut oil, cupuaçu butter, and cocoa butter.

\begin{tabular}{|c|c|c|c|c|c|c|}
\hline Standard & Fatty Acid & Buriti oil & Tucumã butter & Brazil nut oil & Cupuaçu butter & Cocoa butter \\
\hline C8:0 & caprylic & - & 1.67 & - & - & - \\
\hline C10:0 & capric & - & 1.76 & - & - & - \\
\hline C12:0 & lauric & - & 46.81 & - & - & - \\
\hline C14:0 & myristic & - & 22.50 & - & - & - \\
\hline C16:0 & palmitic & 18.24 & 6.70 & 14.53 & 7.03 & 24.91 \\
\hline C16:1 & palmitoleic ${ }^{1}$ & 0.26 & - & 0.28 & - & - \\
\hline C17:0 & margaric & - & - & - & - & 0.24 \\
\hline C18:0 & stearic & 3.77 & 4.96 & 11.43 & 34.38 & 39.93 \\
\hline C18:1 & oleic ${ }^{2}$ & 69.48 & 11.92 & 30.22 & 41.47 & 31.45 \\
\hline C18:2 & linoleic ${ }^{3}$ & 7.41 & 2.92 & 43.08 & 3.17 & 2.16 \\
\hline C18:3 & linolenic ${ }^{3}$ & 0.83 & - & - & - & - \\
\hline C20:0 & arachidic & - & 0.76 & 0.46 & 11.92 & 1.31 \\
\hline C22:0 & behenic & - & - & - & 2.04 & - \\
\hline C22:1 & erucic $^{2}$ & - & - & - & - & - \\
\hline C24:0 & lignoceric & - & - & - & - & - \\
\hline Total & - & 100 & 100 & 100 & 100 & 100 \\
\hline
\end{tabular}

${ }^{1}$ Omega-7; ${ }^{2}$ Omega-9 and ${ }^{3}$ Omega- 6 polyunsaturated fatty acids (PUFAs). The others are saturated fatty acids (SFAs). 
In the standard nomenclature, $\mathrm{C}$ is followed by the number of carbon atoms, colon and the number of double bonds. The values are expressed in percentage $(\%)$ relative to the sum of the areas of the chromatographic peaks for each sample analyzed.

Table 4. Composition of fatty acids of buriti oil (\%) by different literature reports and obtained in the present study.

\begin{tabular}{|c|c|c|c|c|}
\hline \multirow{2}{*}{ Standard } & \multirow{2}{*}{ Fatty Acid } & \multicolumn{2}{|c|}{ Literature data } & \multirow{2}{*}{ Present study } \\
\hline & & $(1,24-26)$ & (11) & \\
\hline C5:0 & valeric & - & 0.95 & - \\
\hline $\mathrm{C} 14: 0$ & myristic & 0.1 & 0.1 & - \\
\hline $\mathrm{C} 16: 0$ & palmitic & $17.34-19.2$ & 17.44 & 18.24 \\
\hline C16:1 & palmitoleic & - & - & 0.26 \\
\hline C18:0 & stearic & 2.0 & 2.18 & 3.77 \\
\hline C18:1 & oleic & $73.3-78.73$ & 70.55 & 69.48 \\
\hline C18:2 & linoleic & $2.4-3.93$ & 7.03 & 7.41 \\
\hline C18:3 & linolenic & 2.2 & 1.08 & 0.83 \\
\hline C20:0 & arachidic & - & 0.27 & - \\
\hline C20:1 & gadoleic* & - & 0.3 & - \\
\hline
\end{tabular}

*0mega-11 PUFA.

Analysis of tucumã butter. According to Morais and Gutjahr (2009), tucumã butter is composed majority by lauric - C12:0 (47.3\%), myristic - C14:0 (26.0 \%), oleic - C18:1 (12.56\%) and palmitic - C16:0 (6.28\%) acids representing together more than $90 \%$. The concentrations of caprylic - C8:0 (0.76\%), capric - C10:0 (1.3\%), stearic - C18:0 (2.65\%) and linoleic - C18:2 $(2.87 \%)$ acids summarize only $7.58 \%$ of total composition (11).

In another study, the composition of tucumã kernel (seed) oil is described as follow: caprylic C8:0 (1.3\%), capric - C10:0 (4.4\%), lauric - C12:0 (48.9\%), myristic - C14:0 (21.6\%), palmitic C16:0 (6.4\%), stearic-C18:0 (1.7\%), oleic-C18:1 (13.2\%) and linoleic acid-C18:2 (2.5\%) (27).
Bora et al. (2001) studied the fatty acids composition of tucumã pulp and kernel oil. These authors observed the following composition of fatty acids: (a) pulp oil: palmitic - C16:0 (14.0\%), stearic - C18:0 (9.8\%), oleic - C18:1 (46.81\%), linoleic - C18:2 (26.13\%) and arachidic - C20:0 $(0.82 \%)$; and (b) kernel oil: for the caprylic - C8:0 $(1.93 \%)$, capric $-\mathrm{C} 10: 0$ (1.95\%), lauric - C12:0 (50.16\%), myristic - C14:0 (24.44\%), palmitic C16:0 (6.21\%), stearic - C18:0 (2.34\%), C18:1 $(8.36 \%)$, linoleic - C18:2 (4.16\%) and arachidic C20:0 (0.10\%) for the kernel oil (10).

The comparison of the results obtained in the present study and reported by cited authors are shown in Table 5. 
Table 5. Fatty acid composition (\%) of tucumã pulp oil and tucumã kernel (seed) oil by different literature reports and obtained in the present study (tucumã butter).

\begin{tabular}{|c|c|c|c|c|c|c|}
\hline \multirow{2}{*}{ Standard } & \multirow{2}{*}{ Acid } & \multirow{2}{*}{\begin{tabular}{|r|} 
Pulp oil \\
$(10)$
\end{tabular}} & \multicolumn{3}{|c|}{ Kernel oil } & \multirow{2}{*}{ Present study } \\
\hline & & & $(27)^{1}$ & $(10)^{1}$ & $(11)^{2}$ & \\
\hline C8:0 & caprylic & - & 1.3 & 1.93 & 0.76 & 1.67 \\
\hline C10:0 & capric & - & 4.4 & 1.95 & 1.3 & 1.76 \\
\hline C12:0 & lauric & - & 48.9 & 50.16 & 47.3 & 46.81 \\
\hline C14:0 & myristic & - & 21.6 & 24.44 & 26.0 & 22.50 \\
\hline C16:0 & palmitic & 14.0 & 6.4 & 6.21 & 6.28 & 6.70 \\
\hline C18:0 & stearic & 9.8 & 1.7 & 2.34 & 2.65 & 4.96 \\
\hline C18:1 & oleic & 46.81 & 13.2 & 8.36 & 12.56 & 11.92 \\
\hline C18:2 & linoleic & 26.13 & 2.5 & 4.16 & 2.87 & 2.92 \\
\hline C20:0 & arachidic & 0.82 & - & 0.10 & - & 0.76 \\
\hline
\end{tabular}

${ }^{1}$ Tucumã seed oil; ${ }^{2}$ Tucumã butter.

Table 6. Fatty acid composition of Brazil nut oil (\%) by different literature reports and obtained in the present study employing gas chromatographic (GC) method.

\begin{tabular}{|c|c|c|c|c|c|c|c|c|c|c|}
\hline \multirow{2}{*}{ Standard } & \multirow{2}{*}{$\begin{array}{l}\text { Fatty } \\
\text { acid }\end{array}$} & \multicolumn{8}{|c|}{ Literature data } & \multirow[t]{2}{*}{$\begin{array}{c}\text { Present } \\
\text { study }\end{array}$} \\
\hline & & (28) & (29) & (30) & (34) & (31) & (32) & (33) & (35) & \\
\hline $\mathrm{C} 16: 0$ & palmitic & 13.9 & 14.5 & 13.9 & 15.2 & 15.2 & 15.1 & 13.5 & 14.5 & 14.53 \\
\hline C16:1 & palmitoleic & - & - & - & - & - & - & - & - & 0.28 \\
\hline C18:0 & stearic & 10.3 & 8.3 & 8.1 & 8.8 & 11.6 & 9.5 & 11.8 & 11.5 & 11.43 \\
\hline C18:1 & oleic & 30.5 & 27.2 & 29.0 & 40.9 & 34.5 & 28.8 & 29.1 & 29.4 & 30.22 \\
\hline C18:2 & linoleic & 44.9 & 49.9 & 48.8 & 34.0 & 37.8 & 45.4 & 42.8 & 42.8 & 43.08 \\
\hline C20:0 & arachidic & - & - & - & - & - & - & - & - & 0.46 \\
\hline
\end{tabular}

As shown in Table 5, the higher values of concentrations of fatty acids, lauric - C12:0, myristic - C14:0, palmitic - C16:0 and oleic C18:1 reported in this study agree with the results from the other authors $(10,11,27)$. Little differences were observed between the fatty acid compositions of tucumã kernel (seed) oil and the results obtained in this study. These variations could be attributed to the variations of origin, sample conditioning/ storage and/or experimental conditions. However, it was noted that the values of concentrations of fatty acids for the pulp (10) are distinct from the rest.

Analysis of Brazil nut oil. Different authors studied the composition of fatty acids of Brazil nut oil by employing gas chromatographic (GC) methods. In this way, Elias and Bressani (1961), Melo and Mancini Jr (1991), Gutierrez et al. (1997), and Sotero Solis et al. (2001) obtained similar results for the composition of fatty acids in the Brazil nut oil obtained by pressing (28-31) (Table 6). According to these authors, high content of palmitic - C16:0 (13,5-15.2\%), stearic - C18:0 (8.1-11.8\%), oleic - C18:1 (27.2-40.9\%) and linoleic - C18:2 (34.0 - 49.9\%) acids were noticed in Brazil nut oil composition.

Employing similar GC techniques, Venkatachalam and Sathe (2006) also determined the content of fatty acids from Brazil nut oil (32). Ryan et al. (2006) also studied the content of fatty acids and tocopherols in the oil extracted from Brazil nut, walnut, pine, pistachio and cashew applying the same technique (33) and found similar values to those by Venkatachalam and Sathe (2006) (32). As shown in Table 6, in all studies the content of linoleic acid is higher followed by oleic acid except the report by Silva (1997) (34). 
According to the analyzes carried out by Lima (2009), the methyl ester of palmitic acid (C16:0) was the first to be identified. Then, the chromatographic profile revealed the methyl esters of stearic (C18:0), oleic (C18:1), linoleic (C18:2), linolenic (C18:3) and arachidic (C20:0) acids. Other acids were identified and quantified in lower concentrations, such as palmitoleic (C16:1) and myristic (C14:0) acids. These results show that the fatty acid chain size have more influence on the elution than the unsaturation number of compounds, in other words, the smaller the chain the less the retention time in the chromatograph (35). Furthermore, the retention time ( $\mathrm{min}$ ) of each methyl esters of palmitic (C16:0), stearic (C18:0), oleic (C18:1), linoleic (C18:2), linolenic (C18:3) and arachidic (C20:0) were $8.72,14.62,15.38,17.22,19.86$ and 23.21 and their percentages (\%) 14.51, 11.45, $29.40,42.82,0.07$ and 0.26 , for the analyzed sample measured by the area of the peak in the chromatogram, respectively. Chromatographic analysis revealed the composition of Brazil nut oil fatty acids have high unsaturation (72.2\%) due to oleic - C18:1 (29.4\%) and linoleic-C18:2 (42.82\%) acids (35).

Thus, based on the data presented in the Table 6 , it is possible to conclude that the values obtained using GC-FID in this study are very close to those found in the scientific literature. The exceptions in the present study were the detections of small fractions of C16:1 - palmitoleic $(0.28 \%)$ and $\mathrm{C} 20: 0$ - arachidic acid $(0.46 \%)$. These variations could be attributed to the variations of origin of Brazil nut, sample conditioning/storage and/or variations of experimental conditions in each study.

Table 7. Composition of fatty acids of cupuaçu butter (\%) by different literature reports and obtained in the present study.

\begin{tabular}{|c|c|c|c|c|c|}
\hline \multirow{2}{*}{ Standard } & \multirow{2}{*}{ Fatty Acid } & \multicolumn{3}{|c|}{ Literature data } & \multirow{2}{*}{ Present study } \\
\hline & & (37) & $(36)$ * & (38) & \\
\hline C14:0 & myristic & - & 0.08 & - & - \\
\hline C16:0 & palmitic & 7.00 & 11.25 & 7.46 & 7.03 \\
\hline C16:1 & palmitoleic & - & 0.40 & 0.07 & - \\
\hline C17:0 & margaric & - & - & 0.16 & - \\
\hline C18:0 & stearic & 34.20 & 38.09 & 31.55 & 34.38 \\
\hline C18:1 & oleic & 41.90 & 38.79 & 42.54 & 41.47 \\
\hline C18:2 & linoleic & - & 2.39 & 5.86 & 3.17 \\
\hline C18:3 & linolenic & - & 0.22 & 0.16 & - \\
\hline C20:0 & arachidic & 11.20 & 7.97 & 10.02 & 11.92 \\
\hline C20:1 & gadoleic & - & - & 0.35 & - \\
\hline C22:0 & behenic & - & 0.74 & 1.61 & 2.04 \\
\hline $\mathrm{C} 24: 0$ & lignoceric & - & - & 0.23 & - \\
\hline
\end{tabular}

*SATs (58.13\%), monoSATs (39.19\%), PUFAs (2,61\%).

Analysis of cupuaçu butter. According to Cohen and Jackix (2009), the main fatty acids present in cupuaçu butter are: palmitic - C16:0 (11.25\%), stearic - C18:0 (38.09\%), oleic - C18:1 $(38.79 \%)$ and arachidic - C20:0 (7.97\%) acids representing a total of $96.10 \%$ (36). Luccas (2001) reported that the composition of fatty acids in cupuaçu butter are palmitic - C16:0 (7.00), oleic - C18:1 (41.9\%) and arachidic - C22:0 (11,2\%) acids (37). Silva and Pinho (2013) found that oleic - C18:1 (42.54\%) and stearic - C18:0 (31.55\%) acids were the are the most abundant in cupuaçu butter, followed by arachidic - C22:0 (10.02\%) and palmitic - C16:0 (7.46\%) acids (38).According to the values in Table 7 , the values of results obtained in present study are close to those of the literature, especially those obtained by Luccas (2001) and Silva and Pinho (2013) (37,38), with the exception 
of the detection of a small fraction of C22:0 behenic acid $(2.04 \%)$ in the present study, which have correspondence to the result reported by Cohen and Jackix (2009) (36).

Analysis of cocoa butter. The fatty acid composition of cocoa butter is one of the most important indicators of its chemical properties. Four major fatty acids that include palmitic acid - C16:0 (24.4\%), stearic acid - C18:0 (33.6\%), oleic acid - C18:1 (37.0\%), and linoleic acid - C18:2 (3.4\%) represent more than $98 \%$ of the total fatty acids present in commercial cocoa butter. Depending on the origin of the cocoa butter, the amounts of these fatty acids vary within narrow ranges $(19,20)$.

Mirante (2007) determined the percentages of cocoa butter fatty acids identified as triglyceride methyl esters of vegetable oils obtained by transesterification process (39). The results presented for palmitic - C16:0, stearic - C18:0, oleic - C18:1, linoleic - C18:2 fatty acids were respectively $19.6 \%, 38.4 \%, 26.2 \%, 1.0 \%$, summarizing 85,2\%.

According to Cohen and Jackix (2009), the three main fatty acids found in cocoa butter are palmitic - C16:0 (38.32\%), stearic - C18:0 (33.54\%), and oleic-C18:1 (24.67\%), representing $96.53 \%$ of total fatty acids (36). Other ones were found in concentrations of less than $2 \%$.

Lipp and Anklam (1998) carried out a comparative study between the concentrations of fatty acids utilizing samples of cocoa butter from different countries, demonstrating that the composition of the cocoa butter presents low variation among the world producer regions (40). The results of these studies in comparison to those obtained in the present study are shown in Table 8 .

Those results are according to that obtained in the present study, in which the predominant fatty acids are palmitic, stearic and oleic acids. Together, these acids are responsible for more than $90 \%$ of the cocoa butter composition. Overall, comparing them with the results from previous studies (Table 8 ), they present close values. The exceptions in this study were the detection of a small fraction of C17:0 - margaric acid $(0.24 \%)$ and no detection of C18:3 - linoleic acid and C22:0 - behenic acid. These variations could be attributed to the variations of origin of cocoa butter, sample conditioning/storage and/or variations of experimental conditions.

Table 8. Fatty acid composition of cocoa butter (\%) by different literature reports, world producer regions, and the obtained in the present study.

\begin{tabular}{|c|c|c|c|c|c|c|c|c|c|c|c|}
\hline \multirow{2}{*}{ Standard } & \multirow{2}{*}{ Fatty Acid } & \multicolumn{3}{|c|}{ Literature data } & \multicolumn{6}{|c|}{ Cocoa butter origin $(40)$} & \multirow{2}{*}{$\begin{array}{c}\text { Present } \\
\text { study }\end{array}$} \\
\hline & & (39) & (19) & $(36) *$ & Brazil & Ecuador & Ghana & $\begin{array}{l}\text { Ivory } \\
\text { Coast }\end{array}$ & Malaysia & Java & \\
\hline C14:0 & myristic & & & & - & - & - & - & - & - & - \\
\hline C16:0 & palmitic & - & - & 0.13 & 25.1 & 25.6 & 25.3 & 25.8 & 24.9 & 24.1 & 24.91 \\
\hline C16:1 & palmitoleic & 19.6 & 24.4 & 38.32 & - & - & - & - & - & - & - \\
\hline $\mathrm{C} 17: 0$ & margaric & - & - & 0.72 & - & - & - & - & - & - & 0.24 \\
\hline C18:0 & stearic & - & - & - & 33.3 & 36.0 & 37.6 & 36.9 & 37.4 & 37.3 & 39.93 \\
\hline C18:1 & oleic & 38.4 & 33.6 & 33.54 & 36.5 & 34.6 & 32.7 & 32.9 & 33.5 & 34.3 & 31.45 \\
\hline C18:2 & linoleic & 26.2 & 37.0 & 24.67 & 3.5 & 2.6 & 2.8 & 2.8 & 2.6 & 2.7 & 2.16 \\
\hline C18:3 & linolenic & 1.0 & 3.4 & 1.84 & 0.2 & 0.1 & 0.2 & 0.2 & 0.2 & 0.2 & - \\
\hline C20:0 & arachidic & - & - & 0.10 & 1.2 & 1.0 & 1.2 & 1.2 & 1.2 & 1.2 & 1.31 \\
\hline C22:0 & behenic & - & - & 0.62 & 0.2 & 0.1 & 0.2 & 0.2 & 0.2 & 0.2 & - \\
\hline
\end{tabular}

*Saturated fatty acids - SFAs (72.66\%), monounsaturated fatty acids - monoUFAs (25.39\%), polyunsaturated fatty acids - PUFAs $(1.94 \%)$; 


\section{CONCLUSION}

Thus, in this study, five Amazonian non-polar vegetal extracts (buriti oil, tucumã butter, Brazil nut oil, cupuaçu butter and cocoa butter) were characterized employing Fourier transform infrared spectroscopy (FTIR) and gas chromatography with flame-ionization detection (GC-FID).

Brazil nut oil and cocoa, tucumã and cupuaçu butters presented close results in FTIR analysis, which the assignments were based on the correlations with fatty acids. No data were found in the literature regarding the comparison of these findings. Analysis of buriti oil spectrum is similar to the previous literature.

Taking into account the percentage of fatty acids by GC-FIC analysis, for all analyzed extracts the obtained findings in the present study presented similarities in comparison with previous data reported in literature. Respect the variations, considered in terms of composition and percentages, could be attributed to the variations of origin of oils, sample conditioning/storage and/or experimental conditions.

There is a general market trend to the search for products that are not harmful to nature, generate economic advantages and make it possible the social development. Amazonian plant extracts are being studied by several researchers due to their promising properties in the use of its products or/and by-products with broad applications.

Finally, the presented findings could be useful to future researches for the chemical characterization and application of Amazon flora extracts, as well as, production of products in food, pharmaceutical, cosmetic, textile and other industrial sectors.

\section{ACKNOWLEDGMENT}

The authors thank Chemyunion (Brazil) and its staff for assisting in CG-FID analysis.

\section{REFERENCES}

1. Albuquerque MLS, Guedes I, Alcantara P, Moreira SGC. Infrared absorption spectra of Buriti (Mauritia flexuosa L.) oil. Vib Spectrosc. 2003;33(1-2): 127-131. DOI: 10.1016/S0924-2031(03)00098-5

2. Cantu-Jungles TM, Almeida CP, Iacomini M, Cipriani TR, Cordeiro LMC. Arabinan-rich pectic polysaccharides from buriti (Mauritia flexuosa): an Amazonian edible palm fruit. Carbohydr Polym. 2015;122: 276-281. DOI: 10.1016/j.carbpol.2014.12.085.

3. Oliveira AIT, Mahmoud TS, Nascimento GNL, Silva JFM, Pimenta RS, Morais PB. Chemical composition and antimicrobial potential of palm leaf extracts from babaçu (Attalea speciosa), buriti (Mauritia flexuosa), and macauba (Acrocomia aculeata). Sci World J. 2016;2016: 1-5. DOI: $10.1155 / 2016 / 9734181$

4. Willerding AL, Carvalho Neto FGMR, Matos da Gama A, Carioca CRF. Hydrolytic activity of bacterial lipases in Amazonian vegetable oils. Quím Nova. 2012;35(9):17821786. DOI: $10.1590 / \mathrm{S} 0100-40422012000900015$

5. Costa GB, Douglas D, Fernandes S, Gomes AA, Almeida E, Veras G. Using near infrared spectroscopy to classify soybean oil according to expiration date. Food Chem. 2016;196:539-543. DOI: 10.1016/j. foodchem.2015.09.076.
6. Santos MDFG, Alves RE, Brito ESDB, Silva SDM, Silveira MRS. Quality characteristics of fruits and oils of palms native to the Brazilian Amazon. Rev Bras Frutic. 2017;39(Spe.):1-6. DOI: 10.1590/0100-29452017 305

7. Rodrigues JE, Araujo ME, Azevedo FFM, Machado NT. Phase equilibrium measurements of Brazil nut (Bertholletia excelsa) oil in supercritical carbon dioxide. J Supercrit Fluids. 2005;34: 223-229. DOI: 10.1016/j. supflu.2004.11.018

8. Leonardi B. Amazonian plant extracts on textile process: physicochemical characterization and application. [Master's dissertation]. São Paulo (Brazil): School of Arts, Sciences and Humanities, University of São Paulo. 2016.

9. Koolen HHF, Silva FMA, Gozzo FC, Souza AQL, Souza ADL. Antioxidant, antimicrobial activities and characterization of phenolic compounds from buriti (Mauritia flexuosa L. f.) by UPLC-ESI-MS/ MS. Food Res Int. 2013;51:467-473. DOI: 10.1016/j. foodres.2013.01.039

10. Bora PS, Narain N, Rocha RVM, Oliveira Monteiro AC, Azevedo Moreira R. Characterization of the oil and protein fractions of tucumã (Astrocaryum vulgare Mart.) fruit pulp and seed kernel - Caracterización de 
las fracciones proteicas y lipídicas de pulpa y semillas de tucumán (Astrocaryum vulgare Mart.). Cienc Tecnol Aliment (CyTA - J Food). 2001;3(2): 111-116. DOI: 10.1080/11358120109487654

11. Morais LRB, Gutjahr E. Chemistry of vegetable oils: valorization of Amazonian biodiversity. Brasilia (Brazil): German Agency of Technical Cooperation (GTZ). 2009. http://www.aboissa.com.br/palestras/download/22/13 cartilha_oleo_30nov_163600.pdf

12. Aguiar JPL. Table of nutrients composition of Amazonian foods. Acta Amaz. 1996; 26(1/2):121-126. DOI: 10.1590/1809-43921996261126.

13. Sagrillo MR, Garcia LFM, Souza Filho OC, Duarte MMMF, Ribeiro EE, Cadona FC, Cruz IBM. Tucuma fruit extracts (Astrocaryum aculeatum Meyer) decrease cytotoxic effects of hydrogen peroxide on human lymphocytes. Food Chem. 2015;173: 741-748. DOI: 10.1016/j.foodchem.2014.10.067

14. De La Cruz S, Maria Lopez-Calleja I, Alcocer M, Gonzalez I, Martin R, Garcia T. TaqMan real-time PCR assay for detection of traces of Brazil nut (Bertholletia excelsa) in food products. Food Control. 2013;33: 105113. DOI: 10.1016/j.foodcont.2013.01.053

15. Yang J. Brazil nuts and associated health benefits: a review. LWT - Food Sci Technol. 2009;42(10):15731580. DOI: 10.1016/j.lwt.2009.05.019

16. Fleck CA, Newman M. Advanced Skin Care - A Novel Ingredient. J Am Coll Clin Wound Spec. 2012;4(4):9294. DOI: 10.1016/j.jccw.2014.02.002

17. Teixeira MFS, Andrade JS, Fernandes OCC, Duran N, Lima Filho JL. Quality attributes of cupuaçu juice in response to treatment with crude enzyme extract produced by Aspergillus japonicus 586. Enzyme Res. 2011;2011:1-6. DOI: 10.4061/2011/494813

18. Azevedo ABA, Kopcak U, Mohamed RS. Extraction of fat from fermented cupuaçu seeds with supercritical solvents. J Supercrit Fluids. 2003;27(2):223-237. DOI: 10.1016/S0896-8446(02)00240-1

19. Shekarchizadeh H, Kadivar M, Ghaziaskar HS, Rezayat M. Optimization of enzymatic synthesis of cocoa butter analog from camel hump fat in supercritical carbon dioxide by response surface method (RSM). J Supercrit Fluid. 2009;49:209-215. DOI: 10.1016/j. supflu.2009.03.005

20. Jahurul MHA, Zaidul ISM, Nik Norulaini NA, Sahena F, Kamaruzzaman BY, Ghafoor K, Omar AKM. Cocoa butter replacers from blends of mango seed fat extracted by supercritical carbon dioxide and palm stearin. Food Res Int. 2014;65(Part C):401-416. DOI: 10.1016/j. foodres.2014.06.039
21. CALTECH. Nicolet FR-IR User's Guide. Madison/WI (USA): Thermo Electro Corporation. 2004. [citad 2018 Apr 27]. 164 p. Available from: http://mmrc.caltech.edu/ FTIR/Nicolet/Nicolet Software/Nicolet 2/4700_6700 User.pdf

22. AGILENT. Agilent 6890 Gas Chromatograph. Wilmington/DE (USA): Agilent Technologies, Inc. 2007. [citad 2018 Apr 27]. 258 p. Available from: http:// www.chem.eng.psu.ac.th/new_chem/upload/manual/53/ Maintaining\%20\%20GC\%206890.pdf

23. Stuart B. Infrared Spectroscopy: fundamentals and applications. Chichester (UK): John Wiley \& Sons, Inc.; 2005.

24. Villachica H, Carvalho JEU, Muller CH, Diaz SC, Almanza M, Frutales y hortalizas promisorios de la Amazonia. Lima (Perú): Tratado de Cooperación Amazónica, Secretaria Pro-Tempore, TCA-SPT Publicaciones, 44. 1996.

25. Bastos ACLM, Assunção FP. Oxidação dos óleos de tucumã (Astrocaryum vulgare Mart.) e buriti (Mauritia flexuosa Mart.). In: Faria LJG, Costa CML, editor. Tópicos Especiais em Tecnologia de Produtos Naturais. Série Poema, n. 7. Belém (Brasil): UFPA; 1998. p. 29-40.

26. Pastore Jr F, Araujo VF, Petry AC, Echeverria RM, Fernandes EC, Leite FHF. Plantas da Amazônia para produção cosmética. Brasília/DF (Brasil): Universidade de Brasília - Laboratório de Tecnologia Química (LATEC), Organização Internacional de Madeiras Tropicais (OIMT) e Fundação de Estudo e Pesquisas em Administração e Desenvolvimento (FEPAD). 2007.

27. Veloso FDAP, Amoedo MSBDC, Ayrton A. Plantas medicinais e suas aplicações na indústria. Manaus (Brasil): FIEAM/DAMPI. 1996.

28. Elias LG, Bressani R. The nutritive value of the Brazil nut oil. J Am Oil Chem Soc. 1961; 38(8): 450-452.

29. Melo MDOM, Mancini Filho J. Antioxidantes naturais da castanha-do-Brasil (Bertholletia excelsa, h b r). Ciênc Tecnol Aliment. 1991;11(2):252-263.

30. Gutierrez EMR, Regitano-D'Arce MAS, Rauen-Miguel AMO. Estabilidade oxidativa do óleo bruto da castanhado-Pará (Bertholletia excelsa). Ciênc Tecnol Aliment. 1997;17(1):22-27.

31. Sotero Solis V, Gioielli LA, PolakiewiczB. Hydrogenation and interesterification of Brazil nut oil (Bertholletia excelsa). Grasas Aceites. 2001;52(3-4):192-197. DOI: 10.3989/gya.2001.v52.i3-4.356

32. Venkatachalam M, Sathe SK. Chemical composition of selected edible nut seeds. J Agric Food Chem. 2006;54:4705-4714. DOI: 10.1021/jf0606959 
33. Ryan E, Galvin K, O’Connor TP, Maguire AR, O’Brien NM. Fatty acid profile, tocopherol, squalene and phytosterol content of Brazil, pecan, pine, pistachio and cashew nuts. Int J Food Sci Nutr. 2006;57(3/4):219-228. DOI: 10.1080/09637480410001725175

34. Silva MV. Determination of critical HLB of babassu oil, evaluation of moisturizing function and application in topical emulsions as a new lipophilic adjuvant. [Master's dissertation]. Recife (Brazil): Pharmaceutical Sciences, Federal University of Pernambuco. 1997

35. Lima CRRC. Identification of fatty acids containing in the Brazil nut oil in cosmetics emulsions. [Master's dissertation]. São Paulo (Brasil): School of Pharmaceutical Sciences, University of São Paulo. 2009.

36. Cohen KDO, Jackix MDNH. Chemical and Physical Characteristics of Cupuaçu's Fat and Cocoa's Butter. Planaltina/DF (Brazil): Embrapa Cerrados - Documentos 269. 2009.
37. Luccas V. Thermal fractioning and obtaining of alternative cupuaçu fats to cocoa butter for use in chocolate manufacture. [PhD thesis]. Campinas (Brasil): Chemical Engineering School, University of Campinas. 2001.

38. Silva JC, Pinho SC. Viability of the microencapsulation of a casein hydrolysate in lipid microparticles of cupuaçu butter and stearic acid. Int J Food Stud. 2013;2(1):48-59. DOI: $10.7455 / \mathrm{ijfs} / 2.1 .2013 . \mathrm{a} 4$

39. Mirante FIC. Characterization by gas chromatography of vegetable oils and paraffin waxes. [Master's dissertation]. Aveiro (Portugal): Chemistry Department, University of Aveiro. 2007.

40. Lipp M, Anklan E. Review of cocoa butter and alternative fats for use in chocolate - Part A. Compositional data. Food Chem. 1998;62(1):73-97. DOI: 10.1016/S03088146(97)00160-X 